\title{
Scottish Gaelic Language
}

National Cancer Institute

\section{Source}

National Cancer Institute. Scottish Gaelic Language. NCI Thesaurus. Code C153930.

An Indo-European Celtic language native to the Gaels of Scotland. 